\title{
. \\ HIV-1 Trans Infection via TNTs Is Impeded by Targeting C5aR
}

\author{
Giulia Bertacchi, Wilfried Posch $(\mathbb{D}$ and Doris Wilflingseder *(D)
}

check for updates

Citation: Bertacchi, G.; Posch, W.; Wilflingseder, D. HIV-1 Trans Infection via TNTs Is Impeded by Targeting C5aR. Biomolecules 2022, 12, 313. https://doi.org/10.3390/ biom12020313

Academic Editors: Renate König and Carsten Münk

Received: 11 January 2022

Accepted: 10 February 2022

Published: 15 February 2022

Publisher's Note: MDPI stays neutral with regard to jurisdictional claims in published maps and institutional affiliations.

Copyright: (C) 2022 by the authors. Licensee MDPI, Basel, Switzerland. This article is an open access article distributed under the terms and conditions of the Creative Commons Attribution (CC BY) license (https:// creativecommons.org/licenses/by/ $4.0 /)$.
Institute of Hygiene and Medical Microbiology, Medical University of Innsbruck, 6020 Innsbruck, Austria; giulia.bertacchi@i-med.ac.at (G.B.); wilfried.posch@i-med.ac.at (W.P.)

* Correspondence: doris.wilflingseder@i-med.ac.at; Tel.: +43-(0)-512-9003-70704

\begin{abstract}
Nonadjacent immune cells communicate through a complex network of tunneling nanotubes (TNTs). TNTs can be hijacked by HIV-1, allowing it to spread between connected cells. Dendritic cells (DCs) are among the first cells to encounter HIV-1 at mucosal sites, but they are usually efficiently infected only at low levels. However, HIV-1 was demonstrated to productively infect DCs when the virus was complement-opsonized (HIV-C). Such HIV-C-exposed DCs mediated an improved antiviral and T-cell stimulatory capacity. The role of TNTs in combination with complement in enhancing DC infection with HIV-C remains to be addressed. To this aim, we evaluated TNT formation on the surface of DCs or DC $/ \mathrm{CD}^{+} \mathrm{T}$-cell co-cultures incubated with non- or complementopsonized HIV-1 (HIV, HIV-C) and the role of TNTs or locally produced complement in the infection process using either two different TNT or anaphylatoxin receptor antagonists. We found that HIV-C significantly increased the formation of TNTs between DCs or DC/CD4 ${ }^{+} \mathrm{T}$-cell co-cultures compared to HIV-exposed DCs or co-cultures. While augmented TNT formation in DCs promoted productive infection, as was previously observed, a significant reduction in productive infection was observed in $\mathrm{DC} / \mathrm{CD}^{+}{ }^{+} \mathrm{T}$-cell co-cultures, indicating antiviral activity in this setting. As expected, TNT inhibitors significantly decreased infection of HIV-C-loaded-DCs as well as HIV- and HIV-C-infected-DC/CD4 ${ }^{+}$ T-cell co-cultures. Moreover, antagonizing C5aR significantly inhibited TNT formation in DCs as well as $\mathrm{DC} / \mathrm{CD}^{+} \mathrm{T}$-cell co-cultures and lowered the already decreased productive infection in co-cultures. Thus, local complement mobilization via DC stimulation of complement receptors plays a pivotal role in TNT formation, and our findings herein might offer an exciting opportunity for novel therapeutic approaches to inhibit trans infection via C5aR targeting.
\end{abstract}

Keywords: HIV-1; complement; tunneling nanotubes (TNTs); trans infection

\section{Introduction}

With 1.5 million new infections in 2020 [1], the HIV-1 pandemic is far from over, with the genetic variability and the global diversity of the virus challenging the development of a curative treatment or vaccine [2].

Although the major targets of HIV-1 infection are CD4 ${ }^{+} \mathrm{T}$ cells, dendritic cells (DCs) play a crucial role in HIV-1 transmission and the shaping of adaptive immunity [3,4]. Indeed, DCs are among the first cells to encounter HIV-1 at the mucosal surface, where they act as a surveillance system, taking up antigens at the site of the infection [5]. Upon contact with the invading pathogen, DCs mature into potent antigen-presenting cells (APCs) and present the acquired antigen to naive $\mathrm{CD} 4^{+} \mathrm{T}$ cells either in mucosal tissue or after migrating to lymph nodes [6-9].

Despite DCs being a vehicle for trans infection, they only show low-level productive infection with HIV-1 due to a number of restriction factors $[10,11]$. Among the most potent restriction mechanisms of HIV-1 infection in DCs is SAM domain HD domain-containing protein 1 (SAMHD1) [12,13]. SAMHD1 blocks HIV-1 at the post-entry step by reducing the intracellular dNTP pool, hence depriving the virus of the required 'building blocks' for its replication [14-16]. 
Interestingly, complement-opsonized HIV-1 (HIV-C) efficiently infects DCs by evading SAMHD1 restriction due to phosphorylation of the T592 residue of the SAM domain, resulting in improved antiviral immune responses [17-23]. Moreover, DCs exposed to HIVC display enhanced maturation and costimulatory capacity [17], as well as the production of type I interferons, compared to DCs exposed to nonopsonized HIV-1, which do not produce type I or III interferons $[18,19,24]$. On the contrary, another study recently illustrated that complement opsonization supports HIV establishment in colorectal mucosa, therefore creating an environment with higher levels of infection compared to the nonopsonized virus [25].

Complement opsonization of HIV-1 is a relevant process in the outcome of viral infection. In fact, the initial host-HIV-1 interaction includes the activation of the complement system via all three signaling cascade pathways [26], which also happens in semen [27]. However, HIV-1 has evolved mechanisms to elicit complement-mediated destruction by incorporating regulators of complement activation during the budding process and additionally binding the fluid-phase factor $\mathrm{H}[28,29]$. Thus, only low levels of HIV-1 particles are destroyed by complement-mediated lysis [29].

In addition, as the viral envelope possesses a complement-binding domain, HIV-C spontaneously accumulates as early as during transmission and the acute phase of infection [18,30-33]. Complement deposition on its surface protects the virus from complementmediated neutralization [34] and increases HIV-1 infectivity through the interaction with complement receptors [22,35].

In 2004, Gerdes and colleagues described a novel route of cell-to-cell communication: long cytoplasmic bridges, mainly made of F-actin, named tunneling nanotubes (TNTs) [36]. TNTs allow the formation of a complex cellular network [37], which, in physiological conditions, facilitates fast and specific responses between different cells through the exchange of organelles, vehicles and the coordination of signals [38]. These structures can either be open-ended, supporting the continuity of the cytoplasm, or closed-ended, allowing only molecular exchange between nonadjacent cells. Immune cells, including B cells, macrophages, dendritic cells, T cells and NK cells, can all form TNTs (as reviewed in [39]), which have particularly been observed between immune cells in lymph nodes [40], as well as between DCs resident in the gut, where they cross the epithelial layer into the gut lumen to access bacteria [41].

Besides their physiological role, TNTs can be hijacked by invading pathogens, which then spread between cells protected by the extracellular environment. In this context, TNTs have previously been demonstrated to favor HIV-1 spread between macrophages and $\mathrm{T}$ cells and also between $\mathrm{T}$ cells themselves [42-48]. Indeed, it has been calculated that transmission of HIV between T cells through TNTs is 100- to 1000-fold higher than through classical cell-free infection [49]. The influence of actin remodeling on HIV infection has previously been demonstrated in $\mathrm{CD}^{+}{ }^{+} \mathrm{T}$ cells, where dynamin inhibition has been linked to infection of impaired cells [50]. In DCs, budding HIV and immature HIV particles have been observed moving inside long actin-rich filopodia, inconsistent with the TNT structure, which converge to form viral synapses with $\mathrm{CD}^{+} \mathrm{T}$ cells [51]. Additionally, DCs have recently been described to display a higher number of TNTs when in co-culture with CD4 ${ }^{+}$ $\mathrm{T}$ cells and in the presence of IFN- $\gamma$. HIV-like particles were found inside these structures, which spanned from one DC to another [52].

To date, the role of complement in the formation of TNTs has not yet been addressed. To this aim, here, we compared the number of TNTs displayed on the surfaces of DCs infected with HIV or HIV-C and collected viral supernatants in parallel as a measure of infection. A similar experiment was performed in which HIV/HIV-C DCs were incubated with either cytarabine (AraC) or TNTi, which are known to inhibit TNT formation by respectively interfering with the NF-kB pathway [53] and M-Sec-dependent TNT formation [43]. Lastly, the role of local complement activation induced in HIV- or HIV-C-exposed DCs or DC/T-cell co-cultures and their role in TNT formation as well as viral spread were 
addressed by incubating infected cells with inhibitors of either C3a or C5a receptors (C3aR and $\mathrm{C} 5 \mathrm{aR})$.

\section{Materials and Methods}

\subsection{Ethics Statement}

All participating blood donors provided written informed consent to the Central Institute for Blood Transfusion and Immunological Department, Innsbruck, Austria. The use of anonymized leftover specimens for research on host/pathogen interactions was approved by the Ethics Committee of the Medical University of Innsbruck (ECS: 1166/2018).

\subsection{Generation of Human Monocyte-Derived DCs and CD4 ${ }^{+} \mathrm{T}$ Cells}

To isolate monocytes, blood was received by the Central Institute for Blood Transfusion and Immunological Department, Innsbruck, Austria. Briefly, peripheral blood mononuclear cells (PBMCs) were isolated from the blood of healthy donors [54] by density gradient centrifugation using a Ficoll Paque Premium (GE Healthcare, Chicago, IL, USA) gradient. After washing, CD14 ${ }^{+}$monocytes were isolated from PBMCs using anti-human CD14 Magnetic Beads (BD); the purity of the isolated cells was assessed by FACS and was at least 98\%. Monocytes were stimulated by adding IL-4 (200 U/mL) and GM-CSF (300 U/mL) for 5 days to generate iDCs, which were then harvested and used for all further experiments.

$\mathrm{CD}^{+} \mathrm{T}$ cells were isolated from PBLs using a human naive $\mathrm{CD} 4^{+} \mathrm{T}$-cell enrichment set (BD). The purity of the isolated cells was assessed by fluorescence-activated cell sorting (FACS) and was at least $98 \%$. CD4 ${ }^{+}$cells were stimulated with $200 \mathrm{U} / \mathrm{mL}$ IL-4 for one day before being used in the following experiments.

\subsection{Multicolor Fluorescence-Activated Cell Sorting (FACS) Analyses}

To assess their purity, multicolor fluorescence-activated cell sorting (FACS) analyses were performed on monocytes immediately after their isolation using antibodies against the following lineage markers: CD3 for T lymphocytes, CD14 for monocytes and CD19 for B lymphocytes. FACS analyses of monocyte-derived DCs were performed on day 5 to measure the expression levels of CD11c, CD83 and DC-SIGN.

FACS analyses of isolated $\mathrm{CD}^{+} \mathrm{T}$ cells were performed to measure the expression levels of CD3, CD4 and CD8.

FACS analyses were performed as previously described [55] on a FACSVerse flow cytometer (BD Biosciences, Franklin Lakes, NJ, USA). Data were analyzed using FACSDiva Software version 8 (BD Biosciences) [56].

\subsection{Plasmids}

The infectious R5-tropic HIV-1 proviral clone R9Bal was used for maturation, binding/internalization and DC infection studies.

Confocal microscopic analyses and HC/HT imaging analyses were performed by using chimeric R9Bal/mCherry and R9Bal/GFP virus preparations originating from R9Bal and vpr/mCherry or /GFP expression plasmids.

\subsection{Virus Production}

HIV-1 proviral clones were produced by transfecting HEK293T cells using the $\mathrm{CaCl} 2$ method [17]. Viral supernatants were collected on several days postinfection (dpi), cleared by filtration through $0.22 \mu \mathrm{m}$ pore-size filters and concentrated by ultracentrifugation at $20,000 \mathrm{rpm}$ for $90 \mathrm{~min}$ at $4^{\circ} \mathrm{C}$. The virus pellet was resuspended in RPMI1640 without supplements and stored in small aliquots at $-80{ }^{\circ} \mathrm{C}$ to avoid multiple thawing. One aliquot was taken to determine the virus concentration by p24 ELISA [57].

\subsection{Virus Opsonization}

To mimic opsonization in vitro, purified HIV-1 and VLP stocks were incubated for $1 \mathrm{~h}$ at $37^{\circ} \mathrm{C}$ with normal human serum (NHS) in a 1:10 dilution. As a negative control, the virus 
was incubated under the same conditions in culture medium. After opsonization, the virus was thoroughly washed to remove unbound components, pelleted by ultracentrifugation $\left(20,000 \mathrm{rpm} / 90 \mathrm{~min} / 4^{\circ} \mathrm{C}\right)$ and resuspended in culture medium without supplements, and virus concentrations were determined using p24 ELISA. The opsonization pattern was analyzed using a virus capture assay (VCA), as described below.

\section{7. $p 24$ ELISA}

To analyze supernatants for HIV p24 capsid protein, after virus production and following an infection experiment, a p24 sandwich ELISA was performed. Briefly, the ELISA plate was coated using a mouse MAb against HIV-1 p24 Ag (200 ng/well). For infection experiments, lysed samples (diluted 1:1 with $2 \%$ Igepal) were added for $1 \mathrm{~h}$ at room temperature. Bound HIV-1 p24 Ag was detected with a second biotinylated anti-p24 MAb followed by streptavidin- $\beta$-galactosidase conjugate. The color reaction was developed with the resorufin- $\beta$-D-galactopyranoside substrate (Sigma-Aldrich, Saint Louis, MI, USA), and the optical density was measured on an ELISA microplate reader at $550 \mathrm{~nm}$. The amount of p24 was calculated from a standard curve by using recombinant HIV-1 p24 Ag. All reagents for p24 ELISA were kindly provided by Polymun Scientific, Klosterneuburg, Austria.

\subsection{Virus Capture Assay}

The opsonization pattern was determined by virus capture assay (VCA) as previously described by our team [20] using anti-human C3c (recognizing C3b, iC3b), C3d, IgG or mouse IgG Abs as controls for background binding. The coated VCA plates were incubated overnight with the differentially opsonized virus preparations ( $2.5 \mathrm{ng}$ p 24 /well) at $4{ }^{\circ} \mathrm{C}$ and washed 5 times, and the bound virus was lysed and transferred to a precoated p24 ELISA plate.

\subsection{Infection of Cells}

In the first experimental setting, DCs were differentially matured (iDCs1:1000 iU / mL IFN $\gamma, \mathrm{mDCs} 1: 1000 \mathrm{iU} / \mathrm{mL}$ IFN $\gamma, 250 \mathrm{ng} / \mathrm{mL}$ LPS, IDCs2: $10^{-6} \mathrm{~mol}$ PGE2 mDCs: $10^{-6} \mathrm{~mol}$ PGE: $250 \mathrm{ng} / \mathrm{mL}$ LPS) for 1 day, co-cultured with $\mathrm{CD}^{+} \mathrm{T}$ cells and infected in duplicates using differentially opsonized HIV-1.

Briefly, in a 96-well U-bottom plate (Greiner Bio-One, Kremsmünster, Austria), $10^{5}$ cells in $100 \mu \mathrm{L} /$ well (in a ratio of $2 \mathrm{CD}^{+} \mathrm{T}$ cells $/ 1 \mathrm{DC}$ in co-cultures) were infected with $25 \mathrm{ng}$ p24/mL of HIV / HIV-C or left uninfected. To confirm productive infection with HIV-1, we thoroughly washed the cells after $24 \mathrm{~h}$ and cultured cells at $37^{\circ} \mathrm{C} / 5 \% \mathrm{CO}_{2}$. Using ELISA, we measured the p24 concentrations in the supernatants after spinning down the plate to pellet cells at $7 \mathrm{dpi}$.

In the second infection experiment, iDCs, $\mathrm{CD} 4^{+}$or $\mathrm{DC} / \mathrm{CD} 4^{+}$co-cultures were seeded in a 96-well U-bottom plate (Greiner Bio-One) $\left(10^{5}\right.$ cells in $100 \mu \mathrm{L} /$ well, in a ratio of $2 \mathrm{CD}^{+} \mathrm{T}$ cells/1 DC in co-cultures) and infected with $25 \mathrm{ng}$ p $24 / \mathrm{mL}$ of HIV / HIV-C or left uninfected. Each condition was then treated for $24 \mathrm{~h}$ with TNT inhibitors: cytarabine (1 $\mu \mathrm{M}$, Sigma-Aldrich) or TNTi (20 $\mu \mathrm{M}$, Pharmeks, Moscow, Russia). After $24 \mathrm{~h}$, cells were thoroughly washed, and supernatants were collected as above at 7 days postinfection. Lastly, the infection experiment setting was repeated by preincubating cells with anaphylatoxin inhibitors (C3aR, C5aRI and C5aRII), both obtained from Sigma-Aldrich: C3aRi (SB 290157) and C5aRi (mix of W-54011 and DF2593, 1:1). Cells were treated for $2 \mathrm{~h}$ with $1 \mu \mathrm{M}$ $\mathrm{C} 3 \mathrm{aR}$ or $\mathrm{C} 5 \mathrm{aR}$ antagonists before infection. After $3 \mathrm{~h}$, cells were thoroughly washed and incubated with $0.1 \mu \mathrm{M}$ anaphylatoxin receptor antagonists for the remaining days before supernatant retrieval.

\subsection{Confocal Analysis}

To quantify intracellular HIV / HIV-C and C3 induction by the differentially opsonized virus by confocal microscopy and to count TNTs, 50,000 cells/well were seeded in Cell- 
Carrier Ultra plates (Perkin Elmer, Waltham, MA, USA), following the three experimental protocols above, and infected with differentially opsonized and fluorescently labeled (GFP or mCherry) HIV-1. After infection, cells were fixed with $4 \%$ paraformaldehyde. Intracellular staining was performed using $1 \times$ Intracellular Staining Permeabilization Wash Buffer $(10 \times$; BioLegend, San Diego, CA, USA).

The following staining protocols were followed for each of the previously described experiments (see "Infection of Cells"). First and second experimental settings: Hoechst 33342 (Cell Signaling Technologies, Danvers, MA, USA), phalloidin-Alexa 647 (Cell Signaling Technologies and CD11c-PE (BD Biosciences) for $1 \mathrm{~h}$ at RT, then thoroughly washed in D-PBS.

Third experimental setting: Hoechst 33342 (Cell Signaling Technologies), phalloidinAlexa 647 (Cell Signaling Technologies) and complement C3 (C3-FITC, Agilent Technologies, Santa Clara, CA, USA) for $1 \mathrm{~h}$ at RT, then thoroughly washed in D-PBS.

Image analysis was performed in a high-throughput manner using the Operetta CLS system (PerkinElmer). Spot analyses, nanotube evaluation and absolute quantification for C3-, HIV / HIV-C-, or C3-/HIV / HIV-C-containing cells were conducted using the Harmony software version 4.8 (Perkin Elmer) [58]. For quantification, at least 1000 cells per condition were analyzed.

In order to be counted as a TNT, no less than one membranous structure must be present that connects two cells, is at least partially nonadherent to the substratum and has a minimum length of $8 \mu \mathrm{m}$. Cells with no TNTs must be within one cell body length of another cell without touching any other cell to be classified as negative [59].

\subsection{Statistical Analysis}

Differences were analyzed by using GraphPad Prism software version 9 (GraphPad Software Inc., San Diego, CA, USA) [60] and one-way ANOVA with Bonferroni post-test for multiple comparisons or unpaired Student's $t$-test depending on the analyses performed.

\section{Results}

\subsection{HIV-C Enhances TNT Formation in DCs and DC/CD4 ${ }^{+}$T-Cell Co-Cultures}

In the first step, we assessed the role of complement opsonization of HIV-1 in TNT formation. For this, immature (iDCs) and mature DCs (mDCs) were exposed to HIV or HIV-C and co-cultured with autologous naïve $\mathrm{CD}^{+} \mathrm{T}$ cells. The number of TNTs displayed on DCs was counted 7 days postinfection (dpi), the same day when productive infection of co-cultures was analyzed, since TNT formation in DCs reaches its maximum at 7 dpi compared to earlier time points (Figure S1, Supplementary Materials). As a negative control for TNT formation, DCs were subjected to the chronic inflammatory mediator $\mathrm{PGE}_{2}$ at the early stages of maturation, which is known to generate DCs that fail to reticulate when cultured with $\mathrm{CD}^{+} \mathrm{T}$ cells [52]. Conversely, IFN $\gamma$, together with CD40L on the surface of $\mathrm{CD}^{+} \mathrm{T}$ cells, stimulates TNT formation in DCs [52], and thus, we used this condition as a positive control for DC reticulation. TNTs appear as straight membranous protrusions rich in F-actin that hover above the substratum and connect two distant cells, which can be assessed using high-content screening and digital phase contrast (DPC). HIV infection enhanced TNT formation in both iDCs and mDCs (Figure 1a), in line with previous observations in macrophages [42,43] and U87 cells [44].

Interestingly, HIV-C-loaded iDCs as well as mDCs displayed a significantly higher number of TNTs on their surface when co-cultured with $\mathrm{CD} 4^{+} \mathrm{T}$ cells (Figure $1 \mathrm{a}, \mathrm{b}$ ) which is particularly impressive when the inevitable loss of some of these structures during chemical fixation is considered [61]. Not only in DC/CD4 ${ }^{+} \mathrm{T}$-cell co-cultures (Figure 1a,b) but also in cultures of DCs alone, HIV-C enhanced TNT formation, but at significantly lower levels compared to the DC $/ \mathrm{CD}^{+}$co-culture (Figure 1c,d), highlighting the importance of CD4 ${ }^{+}$ $\mathrm{T}$ cells for DC reticulation [52]. From qualitative observations, TNTs seem to especially form between heavily infected cells (Figure 1e). Moreover, HIV-C was observed in proximity of 
TNTs (Figure 1f), in line with recent studies, where HIV-like particles were demonstrated to spread from one DC to another through TNTs [52].

Together, these data point to the prominent role of TNTs during HIV, especially HIV-C, infection. However, at this point, whether TNTs contribute to viral spread or, on the contrary, coordinate immune cells for the containment of viral infection remains to be addressed.

\subsection{Investigating DC and DC/CD4 ${ }^{+}$T-Cell Infection with HIV and HIV-C}

To shed light on the role of TNT in HIV or HIV-C infection, productive infection of DCs, alone or in co-cultures with autologous naïve $\mathrm{CD}^{+} \mathrm{T}$ cells, was measured at $7 \mathrm{dpi}$. DCs only showed low-level productive infection with nonopsonized HIV, while infection with HIV-C was highly efficient (Figure 2a), in line with previous findings [17]. Despite significantly higher TNT formation in DC/T-cell co-cultures exposed to HIV-C (Figure 1a), productive infection in these co-cultures was significantly decreased compared to co-cultures exposed to HIV (Figure 2b), in agreement with recent studies that demonstrated a stronger antiviral response upon HIV-C infection [17-23].
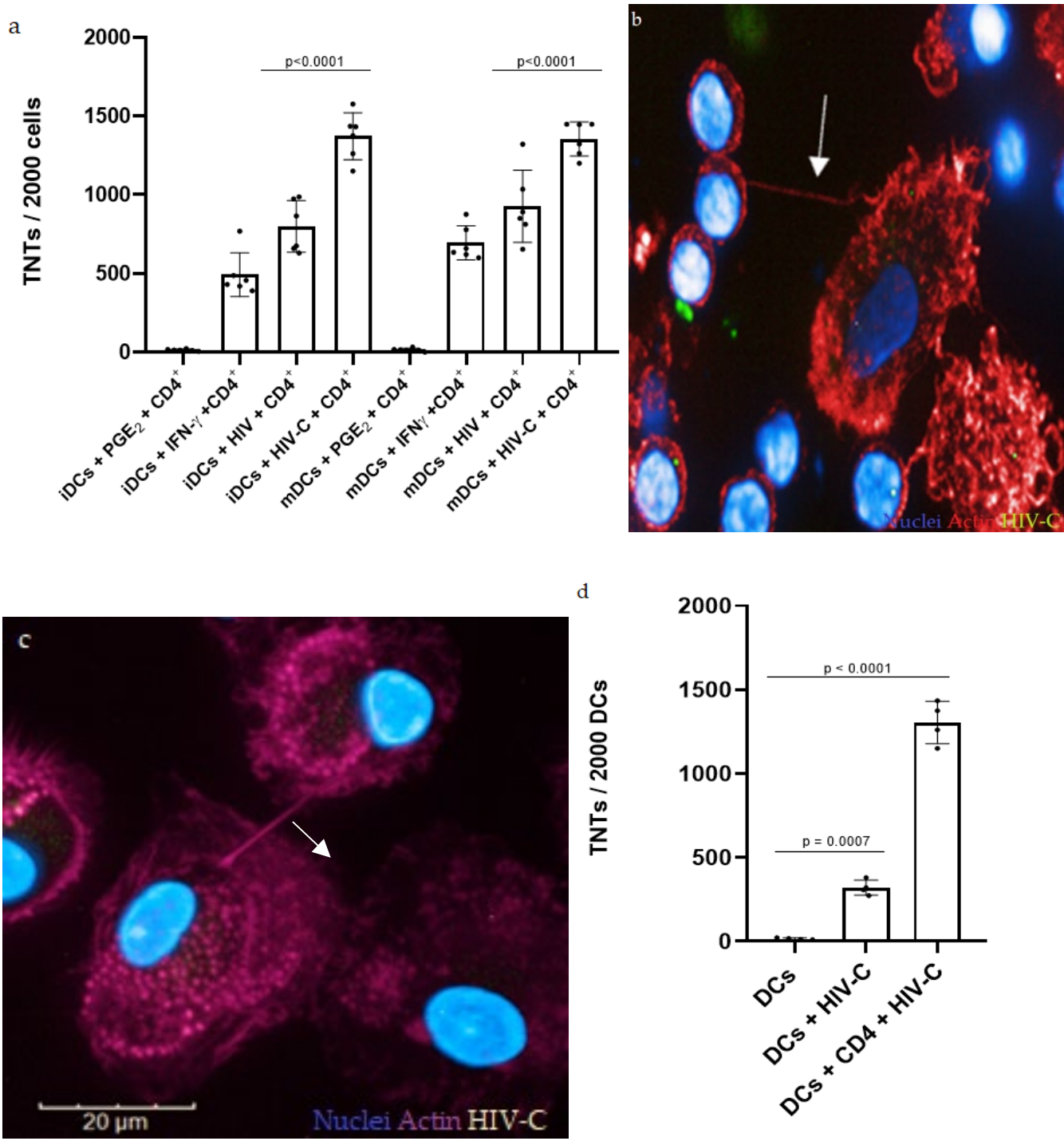

Figure 1. Cont. 


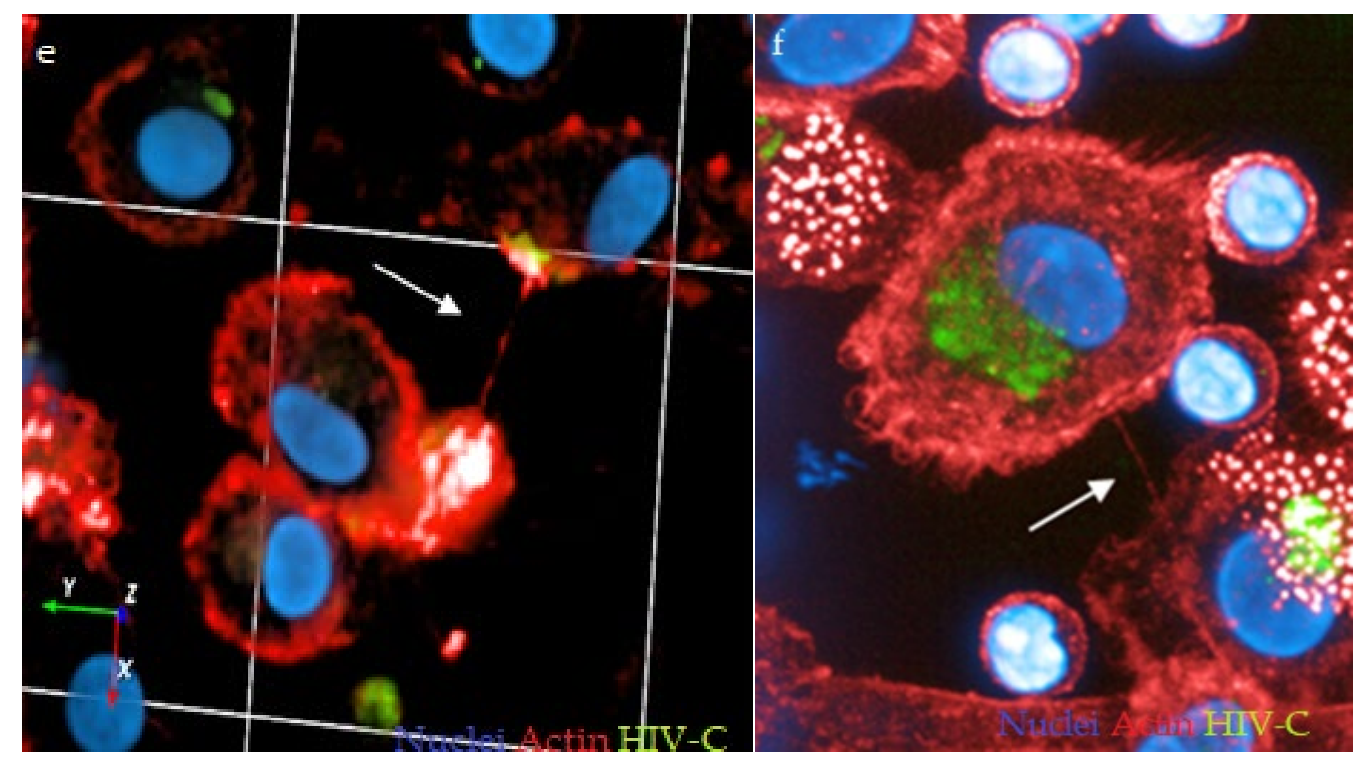

Figure 1. HIV-C increases TNT formation and infection in immature (i) and mature (m) DCs. (a) Quantification of TNTs on HIV/HIV-C-loaded i/mDCs in co-cultures with CD4 ${ }^{+} \mathrm{T}$ cells at 7 dpi. HIV infection induces TNT formation in both $\mathrm{i}$ - and $\mathrm{mDC}$, with complement opsonization of the virus significantly enhancing this tendency $(p<0.0001)$. Experiments were performed for a minimum of 3 independent replicates, and statistical significance was analyzed using GraphPad Prism software v9 [60] and ordinary one-way ANOVA. (b) TNT formation in GFP-HIV-C-infected DC/CD4 ${ }^{+}$T-cell co-culture was observed by confocal microscopy with the high-content screening Operetta system (Perkin Elmer). Nuclei were stained with Hoechst (blue), and F-actin (and therefore TNTs) was stained with phalloidin (red). HIV-C is visible in green. A TNT (highlighted with a white arrow) connects a DC and a CD4 ${ }^{+} \mathrm{T}$ cell. In the absence of cellular membrane staining, $\mathrm{CD} 4^{+} \mathrm{T}$ cells can be distinguished from DCs as round cells with a smaller diameter. Objective: $63 \times$. The acquired image belongs to a single Z-stack, above the cells' substratum. (c) TNT formation in a DC culture infected with mCherry HIV-C was observed by confocal microscopy with the high-content screening Operetta system (Perkin Elmer). Nuclei were stained with Hoechst (blue), F-actin (and therefore TNTs) was stained with phalloidin (fuchsia), and C3 was stained with FITC (green). HIV-C is visible as a yellow spot inside cells. A TNT (indicated by a white arrow) typically lies above cells' substratum and connects two infected DCs. Objective: $63 \times$. Z-series images were acquired at minimal Z interval and later processed together into the "Maximum projection" mode with Harmony software v 4.8 (Perkin Elmer) [58]. (d) TNT quantification on HIV-C-loaded DCs and DC/CD4 ${ }^{+}$T-cell co-cultures at 7 dpi. HIV-C-infected DCs, both alone and in a co-culture with $\mathrm{CD}^{+}{ }^{+} \mathrm{T}$ cells, show a significantly higher number of TNTs on their surfaces. Experiments were performed for a minimum of 3 independent replicates, and statistical significance was analyzed using GraphPad Prism software v9 [60] and unpaired Student's t-test. (e) A 3D reconstruction of a TNT connection (indicated by a white arrow) between GFP-HIV-C-infected DCs. Nuclei were stained with Hoechst (blue), and F-actin (and therefore TNTs) was stained with phalloidin (red). HIV-C is visible in green. Objective: $63 \times$. Z-series images were acquired at minimal $\mathrm{Z}$ intervals and later processed together into the "Maximum projection" mode. From this image, a 3D reconstruction was obtained with the Harmony software (Perkin Elmer) v4.8 [58]. (f) TNT formation in GFP-HIV-C-infected DC/CD4 ${ }^{+}$T-cell co-culture was observed by confocal microscopy with the high-content screening Operetta system (Perkin Elmer). Nuclei were stained with Hoechst (blue), and F-actin (and therefore TNTs) was stained with phalloidin (red). HIV-C is visible in green. A TNT (indicated with a white arrow) connects two HIV-C-loaded DCs. In the absence of cellular membrane staining, $\mathrm{CD} 4^{+} \mathrm{T}$ cells can be distinguished from $\mathrm{DC}$ as round cells with a smaller diameter. Objective: $63 \times$. The acquired image belongs to a single Z-stack, above the cells' substratum. 

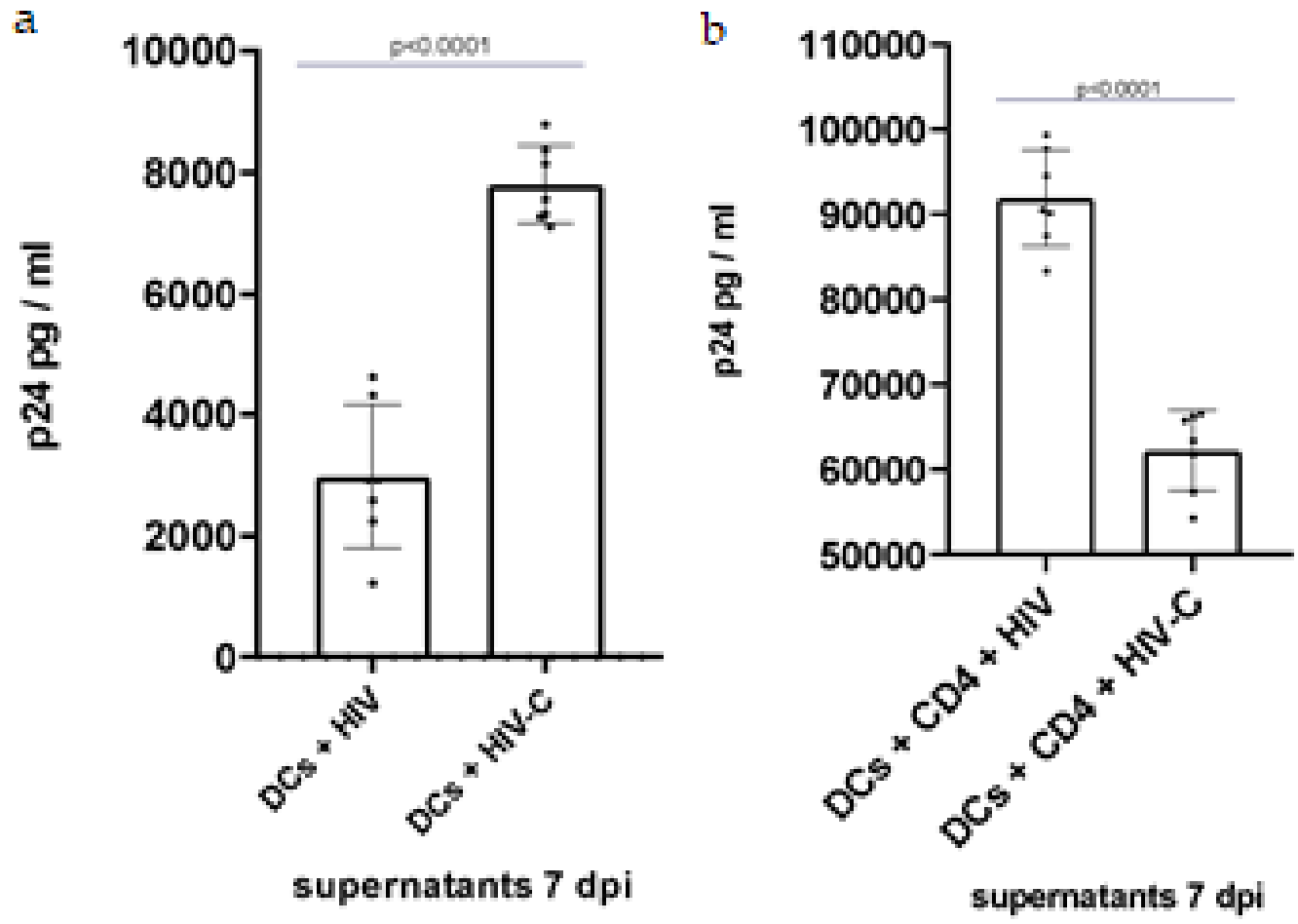

Figure 2. HIV/HIV-C infection of DCs and DC/CD4 ${ }^{+}$T-cell co-cultures. (a) Quantification of infection in 7 dpi supernatants from HIV/HIV-C-infected DCs. DCs incubated with HIV show significantly decreased, moderate productive infection compared to HIV-C $(p<0.0001)$. Experiments were performed for a minimum of 3 independent replicates, and statistical significance was analyzed using GraphPad Prism software v9 [60] and unpaired Student's $t$-test. Abbreviation: dpi: days postinfection. (b) Quantification of infection in 7 dpi supernatants from HIV/HIV-C-infected DC/CD4 ${ }^{+}$T-cell coculture. Infection with HIV-C is decreased and moderate compared to the control infection with HIV $(p<0.0001)$. Experiments were performed for a minimum of 3 independent replicates, and statistical significance was analyzed using GraphPad Prism software v9 [60] and unpaired Student's $t$-test.

\subsection{Inhibition of TNT Formation Decreases Infection in DCs and DC/CD4 ${ }^{+}$Co-Cultures}

To further investigate the role of TNT in HIV/HIV-C infection, DCs, alone or in co-culture with $\mathrm{CD}^{+} \mathrm{T}$ cells, were treated with cytarabine (AraC), which is a pyrimidine nucleoside analog recently demonstrated to reduce TNT formation by interfering with NFKB activation in acute myeloid leukemia (AML) [53] and in HTLV-1 cells [62]. The influence of treatment with AraC on viral infection was determined by measuring p24 concentration in supernatants at 7 dpi. A 50\% infection reduction was observed in DCs, but only if they were infected with HIV-C (Figure 3a). However, when DC/CD4 ${ }^{+}$ T-cell co-cultures were treated with AraC, HIV infection was reduced independently of its opsonization pattern (Figure $3 b$ ). Considering the importance of NFKB in immune cell maturation and development $[63,64]$, the same experiment was repeated using a second TNT inhibitor (TNTi, NPD3064), which blocks TNT formation by interfering with the MSec protein [43].

The results from AraC and TNTi treatment were consistent with those observed using AraC. A decrease in DC infection was observed only when cells were infected with HIV-C (Figure 3c), while in DC/CD4 ${ }^{+}$T-cell co-cultures, productive infection was impeded using both HIV and HIV-C (Figure 3d). Together, these data demonstrate the contribution of TNTs in HIV / HIV-C spread between immune cells. 

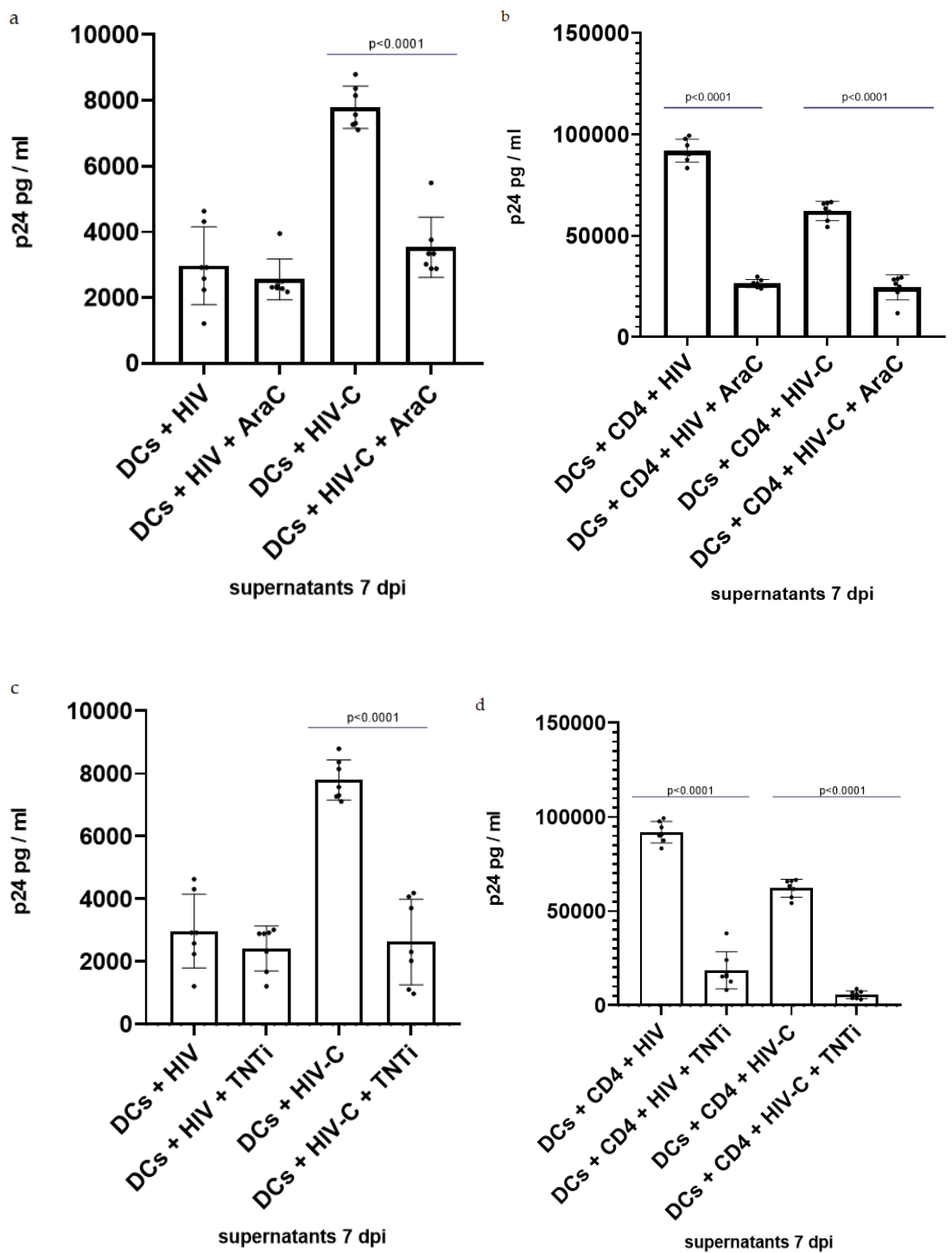

Figure 3. TNT inhibition decreases infection in HIV-C-loaded DCs and in DC/CD4 ${ }^{+}$T-cell co-culture independently of virus opsonization pattern. (a) Quantification of infection in 7 dpi supernatants from HIV / HIV-C-infected DCs with/without $24 \mathrm{~h}$ treatment with $1 \mu \mathrm{M}$ AraC. HIV-C-infected DCs treated with AraC show significantly decreased, moderate productive infection compared to their untreated counterparts $(p<0.0001)$. Experiments were performed for a minimum of 3 independent replicates, and statistical significance was analyzed using GraphPad Prism software v9 [60] and ordinary one-way ANOVA. (b) Quantification of infection in 7 dpi supernatants from HIV/HIV-Cinfected DC/CD4 ${ }^{+}$T-cell co-cultures with/without $24 \mathrm{~h}$ treatment with $1 \mu \mathrm{M}$ AraC. The inhibition of infection is observed to be independent of HIV opsonization $(p<0.0001)$. Experiments were performed for a minimum of 3 independent replicates, and statistical significance was analyzed using GraphPad Prism software v9 [60] and ordinary one-way ANOVA. (c) Quantification of infection in 7 dpi supernatants from HIV / HIV-C-infected DCs with/without $24 \mathrm{~h}$ treatment with $20 \mu \mathrm{M}$ TNTi. HIV-C-infected DCs treated with TNTi show significantly decreased, moderate productive infection compared to their non-treated counterparts $(p<0.0001)$. Experiments were performed for a minimum of 3 independent replicates, and statistical significance was analyzed using GraphPad Prism software v9 [60] and ordinary one-way ANOVA. (d) Quantification of infection in 7 dpi supernatants from $\mathrm{HIV} / \mathrm{HIV}-\mathrm{C}$-infected DC/CD4+ T-cell co-cultures with/without $24 \mathrm{~h}$ treatment with $20 \mu \mathrm{M}$ TNTi. The inhibition of infection is observed to be independent of HIV opsonization $(p<0.0001 ; p<0.001)$. Experiments were performed for a minimum of 3 independent replicates, and statistical significance was analyzed using GraphPad Prism software v9 [60] and ordinary one-way ANOVA. 
3.4. Antagonizing C5aR Reduces TNT Formation, Infection and Local C3 Production in HIV-C-Infected DCs and DC/CD4 ${ }^{+}$T-Cell Co-Cultures

Due to HIV-induced complement activation, the anaphylatoxins C3a and C5a are locally generated upon viral infection. To assess their role in TNT formation, HIV-Cinfected DCs, alone and in co-cultures with $\mathrm{CD}^{+} \mathrm{T}$ cells, were treated with antagonists of $\mathrm{C} 3 \mathrm{a}$ and $\mathrm{C} 5 \mathrm{a}$ receptors $(\mathrm{C} 3 \mathrm{aR}$ and $\mathrm{C} 5 \mathrm{aR})$. The number of TNTs displayed on DCs was counted $7 \mathrm{dpi}$, the same day when productive infection was analyzed. Lastly, internal C3 production by DCs was measured and indicated as percentages (\%) of cells containing $\mathrm{C} 3$ of the total number of observed cells. Interestingly, antagonizing C3aR did not have a major effect on the number of TNTs displayed on the DC surface (Figure 4a), nor on the productive infection of DCs (Figure 4b). On the contrary, incubation with C5aRi led to a significant reduction in the number TNTs on DCs (Figure 4a), accompanied by significantly lower productive infection levels (Figure 4b). Quantification analysis revealed that HIV-C infection was followed by extensive induction of local C3 production in DCs (Figure 4c), with approximately $40 \%$ of cells containing C3. Complement production was clearly visible using confocal microscopy of HIV-C-infected DCs (Figure 4d).

Antagonizing $\mathrm{C} 3 \mathrm{aR}$ and $\mathrm{C} 5 \mathrm{aR}$ was revealed to have antithetic effects on local complement production by DCs: C3aRi resulted in an average increase of $15 \%$ of cells mobilizing intracellular C3 compared to the untreated control. On the contrary, less than $20 \%$ of C5aRi-treated cells mobilized local C3, a value that is significantly lower compared to both untreated control and C3aRi-treated DCs (Figure 4c). Similar results were obtained when $\mathrm{HIV}-\mathrm{C}$-infected DC $/ \mathrm{CD}^{+}{ }^{+} \mathrm{T}$-cell co-cultures were treated with anaphylatoxin receptor antagonists, with only C5aRi significantly decreasing TNT formation (Figure 4a), productive infection (Figure $4 \mathrm{~b}$ ) and complement production (Figure $4 \mathrm{c}$ ), indicating a block in trans infection from DCs to $\mathrm{CD}^{+}{ }^{+} \mathrm{T}$ cells via TNTs. More detailed mechanistic insights are needed to understand these effects on a molecular level, which would have exceeded the scope of the study. Overall, these data suggest that local C3 processing has a role in enabling TNT formation and allowing enhanced interactions between cells, with C5aR having a more prominent role.
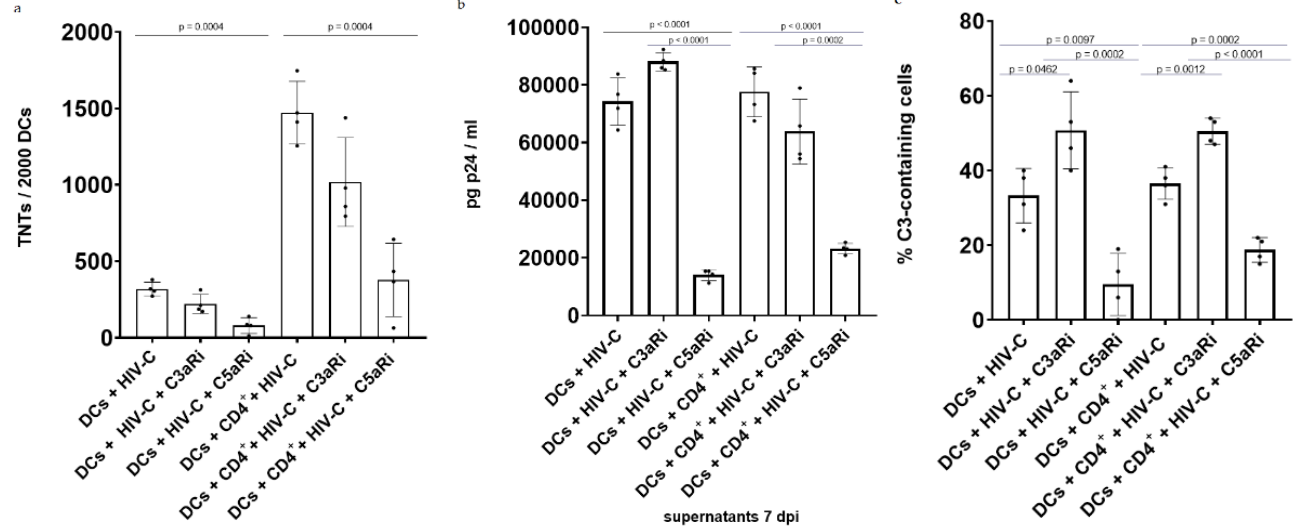

Figure 4. Cont. 


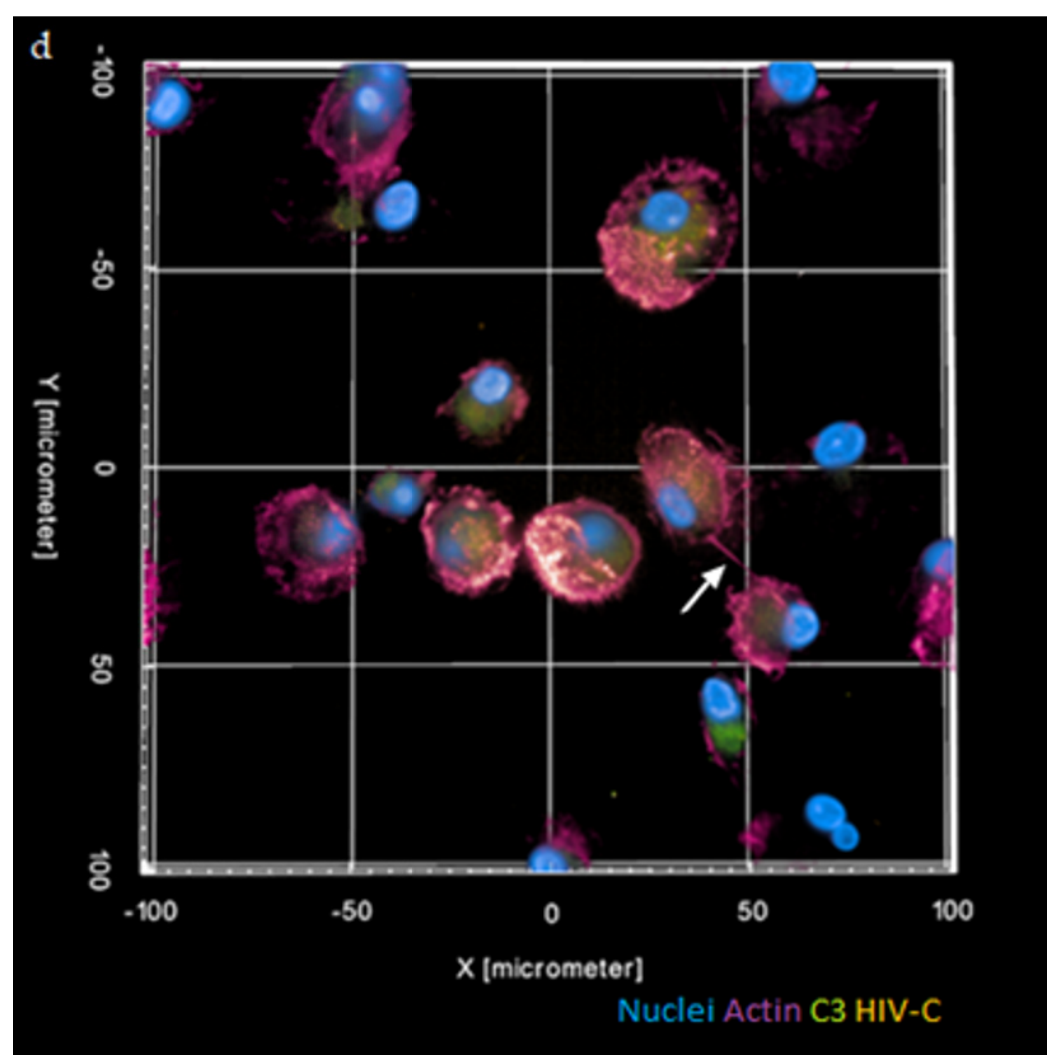

Figure 4. Treatment of HIV-C-infected DCs and DC/CD4 ${ }^{+} \mathrm{T}$-cell co-cultures with antagonists of anaphylatoxin receptors C3aRI and C5aRI/II. (a) Quantification of TNTs on HIV-C-loaded DCs and $\mathrm{DC} / \mathrm{CD}^{+}{ }^{+} \mathrm{T}$-cell co-cultures at $7 \mathrm{dpi}$ with/without treatment with C3aRi and C5aRi. Antagonizing C3aR does not show any effect on TNT formation, while C5aRi-treated DCs display a significant reduction in TNT on their surfaces $(p=0.0004 ; p=0.0004)$. Experiments were performed for a minimum of 2 independent replicates, and statistical significance was analyzed using GraphPad Prism software v9 [60] and ordinary one-way ANOVA. (b) Quantification of productive infection in HIV-C-infected DCs and DC/CD4 ${ }^{+}$T-cell co-cultures with/without treatment with $\mathrm{C} 3 \mathrm{aRi}$ and C5aRi. C3aRi-treated DCs show levels of productive infection with HIV-C equal to the untreated control, while C5aRi-treated cells show decreased infection with HIV-C $(p<0.0001 ; p<0.0001)$. Experiments were performed for a minimum of 2 independent replicates, and statistical significance was analyzed using GraphPad Prism software v9 [60] and ordinary one-way ANOVA. (c) DC complement production was measured as a percentage of C3-containing cells of all observed cells. $\mathrm{C} 3 a \mathrm{Ri}$ treatment significantly increased the percentage of cells containing C3 ( $p=0.0462 ; p=0.0012)$. On the contrary, $\mathrm{C} 5 \mathrm{aRi}$ decreased the percentage of cells producing $\mathrm{C} 3$ compared to both the untreated control ( $p=0.0097 ; p=0.0002)$ and C3aRi-treated DCs $(p=0.0002 ; p<0.0001)$. (d) A 3D reconstruction of a culture of DCs infected with mCherry HIV-C (in yellow). C3 is stained with FITC (green), F-actin (therefore TNTs) is stained with phalloidin (fucshia), and nuclei are stained with Hoechst (blue). A TNT between two productively HIV-C-infected DCs is shown with a white arrow. Objective: $63 \times$. Z-series images were acquired at minimal $\mathrm{Z}$ intervals and later processed together into the "Maximum projection" mode. From this image, a 3D reconstruction was obtained with the Harmony software v4.8 [58] (Perkin Elmer).

\section{Discussion}

Our study highlights the contribution of local complement activation and deposition on the HIV-1 surface for tunneling nanotube (TNT) formation in DCs. Here, we report that HIV infection increases the number of TNTs on DC surfaces, in line with previous observations in macrophages [42,43] and U87 cells [44]. Indeed, recent studies have demonstrated the ability of the accessory HIV protein Nef to hijack macrophages' intercellular 
communication machinery, increasing TNT formation, via a mechanism involving Msec and MyoX that is still not completely understood $[43,65,66]$.

Since HIV-C spontaneously accumulates in semen and during transmission and in the acute phase of infection [18,30-33], we investigated the possible involvement of complement opsonization of the virus in TNT formation. Interestingly, HIV-C mediated a significantly elevated number of TNTs on DCs compared to HIV (Figure 1a). The increased induction of TNTs and reticulation between cells was even further enhanced in DC/CD4 ${ }^{+}$ T-cell co-cultures (Figure 1a,d), consistent with the recently illustrated helper function of CD40L on the CD4 ${ }^{+}$T-cell surface in the initiation of TNT formation [52]. Interestingly, immature and mature DCs did not differ in their ability to form TNTs in response to $\mathrm{HIV} / \mathrm{HIV}-\mathrm{C}$ infection, which can be explained by Nef-induced cytoskeletal arrangement, which renders immature DCs phenotypically and functionally more similar to their mature counterparts [67]. TNTs spanning from one DC to another or between DC/CD4 ${ }^{+} \mathrm{T}$ cells (Figure $1 b, c$ ) were observed in both HIV- and HIV-C-infected cultures, and they were particularly found between heavily infected cells (Figure 1e,f). Moreover, HIV or HIV-C were found in proximity or even inside TNTs, as previously observed in macrophages [42]. In DCs, HIV-like particles have previously been spotted traveling from one DC to another through TNTs [52].

Cell reticulation can help or harm the host depending on the context; indeed, communication mediated by TNTs can induce the immune response of target cells, which may play an important role in the activation and communication of the immune system. This intercellular transport process may, on the one hand, lead to more efficient antigen presentation and T-cell activation and is quite important for an effective cellular immune response [68-70]. On the other hand, many viruses, such as the influenza virus, HIV and herpes simplex virus, can elude host immunity and pharmaceutical targeting by transferring their genome to naïve cells through TNTs [42,53,62,71]. For this reason, we further investigated the effect of complement opsonization or local complement production on TNT formation and infection.

In HIV-C-infected DCs, an increase in TNT number was accompanied by a significantly higher productive infection, which, however, can be explained by the ability of HIV-C to circumvent SAMHD1 via phosphorylation at its T592 residue [17]. Since this is associated with a weakened HIV-C restriction, the resulting increase in infection may play a role in inducing TNTs through the Nef protein. However, when co-cultured with CD4 ${ }^{+} \mathrm{T}$ cells, the higher number of TNTs formed on DC surfaces was accompanied by a lower level of productive infection compared to co-cultures infected with nonopsonized HIV. We previously illustrated that DCs exposed to HIV-C elicit a significantly stronger type I IFN response via a CR4/CCR5/RLR (RIG-I/MDA5)/MAVS/TBK1/IRF3/NFkB signaling axis, and therefore, in co-cultures with $\mathrm{CD}^{+} \mathrm{T}$ cells, the lower level of productive infection despite higher TNT formation could be attributed to this higher type I IFN production and therefore a better antiviral response in HIV-C-infected DCs [18,19].

To shed light on the role of TNTs with respect to DC exposure to complementopsonized HIV, we treated DCs alone or in co-cultures with $\mathrm{CD}^{+}{ }^{+} \mathrm{T}$ cells with cytarabine (AraC), a pyrimidine nucleoside analog recently demonstrated to reduce TNT formation by interfering with NFKB activation in acute myeloid leukemia (AML) [53] and in HTLV-1 cells [62]. TNT inhibition significantly decreased infection in DCs, but only when they were infected with HIV-C but not HIV. HIV induced only low-level productive infection in DCs, which might not be as dependent on viral spread via TNTs as the elevated productive infection observed in HIV-C-exposed DC cultures. The effects mediated by AraC in HIV-C-exposed DCs or DC/T-cell co-cultures could be related to the inactivation of SAMHD1 by HIV-C or by augmented NFkB activation in HIV-C-exposed DCs [17-19]. Indeed, SAMHD1 was recently identified as a biomarker for the cytarabine response, with its depletion in AML cell lines associated with higher cell sensitivity to AraC cytotoxicity in therapeutic doses [72]. Although the concentration of AraC used in our experiments is far from the therapeutic dose, we cannot exclude that the observed decrease in infection 
is related to greater cytotoxic effects of AraC, since the enhanced infection of DCs with HIV-C was accompanied by the highly phosphorylated status of SAMHD1 T592, leading to its inactivation [17]. Additionally, treatment of DC $/ \mathrm{CD} 4^{+} \mathrm{T}$-cell co-cultures using AraC resulted in a decrease in infection, also using nonopsonized HIV. This reduction in HIV infection in co-cultures could be due to the downmodulation of HIV receptor expression in human T lymphoid cells upon cytarabine treatment, which ultimately also reduced cell susceptibility to HIV infection [73]. This is consistent with infection experiments that we additionally performed using $\mathrm{CD}^{+} \mathrm{T}$ cells only, where we detected significantly reduced infection using AraC and nonopsonized HIV-1 (Figure S2, Supplementary Materials). As expected, HIV-C only caused low-level productive infection of $\mathrm{CD}^{+}{ }^{+} \mathrm{T}$ cells regardless of whether they were preincubated or not with AraC due to the low-level expression of complement receptors (Figure S2, Supplementary Materials).

To exclude possible cytotoxic effects of AraC on DCs due to SAMHD1 and considering the importance of NFKB in immune cell maturation and development $[63,64]$, we used a second TNT inhibitor (TNTi), which blocks TNT formation by interfering with the MSec protein [43]. Data using TNTi confirmed the results obtained using AraC, where infection of DC cultures alone or in co-culture with T cells using HIV-C was considerably impeded or completely absent. Therefore, in particular, the antiviral effects observed in DC/CD4 ${ }^{+}$ T-cell co-cultures using HIV-C-exposed DCs were further enhanced in the presence of TNT antagonists, independent of the mechanism of inhibition. As also observed using AraC, TNTi did not have any effect on low-level productive infection of DCs using nonopsonized HIV, while the high transmission of the virus from HIV-loaded DCs to CD4 ${ }^{+} \mathrm{T}$ cells was significantly impaired, indicating the strong involvement of TNTs in virus transfer. In the case of $\mathrm{CD} 4^{+}$T-cell infection, TNTi treatment did not show the same inhibitory effect obtained with AraC on HIV-infected-CD4 ${ }^{+} \mathrm{T}$ cells, which lack the MSec protein (Figure S3, Supplementary Materials). This, together with the fact that HIV-infected T cells do not increase TNT production [49], led us to conclude that the inhibitory effects on HIV infection following treatment with AraC is merely due to its role in the downregulation of HIV receptors [73] and not related to TNT formation. For the same reason, the observed decrease in infection following treatment of the DC/CD4 ${ }^{+} \mathrm{T}$-cell co-culture with TNTi is entirely related to the inability of DCs to reticulate.

Lastly, since we previously found that DCs exposed to HIV-C constantly produce complement-derived anaphylatoxins at mucosal sites and also locally in cells, here, we investigated the role of anaphylatoxins C5a and C3a on TNT formation and productive infection using HIV-C. C5a is a proinflammatory mediator that serves as a potent chemoattractant for iDCs and macrophages, mobilizing them to the site of viral entry during the first stages of infection [74]. We found that C5a stimulates DC reticulation, which is in line with the demonstrated association between proinflammatory stimuli and TNT formation [74]. Antagonizing C5aR led to a decline in TNTs in DC culture as well as in DC/CD4 ${ }^{+} \mathrm{T}_{\text {-cell }}$ co-cultures accompanied by a reduction in viral infection and local C3 production by DCs. Blocking C3aR had opposite effects on TNT formation and viral infection, in accordance with its anti-inflammatory nature [75]. Interestingly, the same pattern was observed when $\mathrm{C} 5 \mathrm{aR}$ and $\mathrm{C} 3 \mathrm{aR}$ were antagonized in nonimmune epithelial cells infected with SARS-CoV-2, with the blocking of $\mathrm{C} 5 \mathrm{aR}$ significantly diminishing TNT formation, infection and internal complement production. Importantly, upon SARS-CoV-2 infection, C3 was largely localized inside TNTs [76]. These findings, together with others, suggest that HIV has evolved a mechanism that involves complement activation to upregulate TNTs to facilitate the spread of infection. In addition to protecting the virus from the extracellular environment, utilizing TNTs to propagate infection is more energetically favorable, since the production of all viral components necessary for replication can be avoided by inserting viral genomes directly into the cytoplasm of a host cell [77].

This study provides novel insights on the mechanisms of TNT formation and utilization for effective HIV infection in terms of complement as an opsonizing agent or upon local C3 mobilization, which is vital for the development of an efficient treatment. As viruses 
and other pathogens have developed the ability to exploit TNTs, so too must modern medicine develop therapeutics that target TNT formation and pathogen spread through them. While we currently have the capabilities to inhibit actin polymerization, less toxic and more specific TNT inhibitors are required.

\section{Conclusions}

In this study, we report that complement opsonization of HIV-1, as well as local complement mobilization and generation of anaphylatoxin $\mathrm{C} 5 \mathrm{a}$, influences productive infection through TNT formation. As expected, TNT antagonists were useful in hindering trans infection of non- and complement-opsonized HIV-1 from DCs to T cells. Surprisingly, C5aR inhibition also significantly blocked TNT formation and intracellular C3 mobilization in DCs as well as productive infection of DCs alone and DC/T-cell co-cultures, rendering $\mathrm{C} 5 \mathrm{aR}$ targeting a promising candidate strategy to block trans infection of $\mathrm{CD}^{+} \mathrm{T}$ cells, the main targets of HIV-1.

Supplementary Materials: The following are available online at https:/ / www.mdpi.com/article/ 10.3390/biom12020313/s1, Figure S1: TNTs formation in a DC /CD4 ${ }^{+} \mathrm{T}$ cell co-culture is enhanced at 7 dpi with HIV/-C compared to lower time points. Figure S2: AraC treatment decreases $\mathrm{CD}^{+} \mathrm{T}$ cells infection with HIV. Figure S3: TNTi treatment does not show any effect on $\mathrm{CD}^{+}{ }^{+} \mathrm{T}$ cells infection with $\mathrm{HIV} /-\mathrm{C}$.

Author Contributions: Conceptualization, G.B., W.P. and D.W.; methodology, G.B. and W.P.; soware, G.B. and D.W.; validation, G.B., W.P. and D.W.; investigation, G.B.; data curation, G.B.; writingoriginal draft preparation, G.B. and D.W.; writing-review and editing, W.P. and D.W.; visualization, G.B.; supervision, D.W.; project administration, D.W.; funding acquisition, D.W. All authors have read and agreed to the published version of the manuscript.

Funding: The authors were supported by Marie Skłodowska-Curie Action (CORVOS EU-H2020MSCA-ITN-2019; grant no. 860064 to D.W.) and the Open Access Funding by the Austrian Science Fund (FWF), grant no. P33510-B to D.W.

Institutional Review Board Statement: The use of anonymized leftover specimens for research on host/pathogen interactions was approved by the Ethics Committee of the Medical University of Innsbruck (ECS: 1166/2018).

Informed Consent Statement: Written informed consent was obtained from all participating blood donors by the Central Institute for Blood Transfusion and Immunological Department, Innsbruck, Austria.

Data Availability Statement: Not applicable.

Acknowledgments: We thank Asma Noureen for her valuable technical support regarding imaging analysis and Thomas J. Hope for providing reagents and virus plasmids. We also thank Polymun Scientific, Klosterneuburg, Austria, who provided all reagents for p24 ELISA. Further reagents were obtained from the Centre for AIDS Reagents, NIBSC HPA UK, supported by the EC FP6/7 Europrise Network of Excellence, and NGIN consortia and the Bill and Melinda Gates GHRC-CAVD Project.

Conflicts of Interest: The authors declare no conflict of interest.

\section{References}

1. Joint United Nations Programme on HIV/AIDS. Global AIDS update. In Confronting Inequalities. Lessons for Pandemic Responses from 40 Years of AIDS; UNAIDS: Geneva, Switzerland, 2021; p. 14.

2. Hemelaar, J. The origin and diversity of the HIV-1 pandemic. Trends Mol. Med. 2012, 18, 182-192. [CrossRef]

3. Steinman, R.M.; Hemmi, H. Dendritic cells: Translating innate to adaptive immunity. Curr. Top. Microbiol. Immunol. 2006, 311, 17-58. [CrossRef] [PubMed]

4. Steinman, R.M. Decisions about dendritic cells: Past, present, and future. Annu. Rev. Immunol. 2012, 30, 1-22. [CrossRef] [PubMed]

5. Shen, R.; Richter, H.E.; Smith, P.D. Early HIV-1 target cells in human vaginal and ectocervical mucosa. Am. J. Reprod. Immunol. 2011, 65, 261-267. [CrossRef] [PubMed]

6. von Andrian, U.; Mempel, T. Homing and cellular traffic in lymph nodes. Nat. Rev. Immunol. 2003, 3, 867-878. [CrossRef] 
7. Bousso, P.; Robey, E. Dynamics of CD8 ${ }^{+} \mathrm{T}$ cell priming by dendritic cells in intact lymph nodes. Nat. Immunol. 2003, 4, 579-585. [CrossRef] [PubMed]

8. Lutz, M.; Schuler, G. Immature, semi-mature and fully mature dendritic cells: Which signals induce tolerance or immunity? Trends Immunol. 2002, 23, 445-449. [CrossRef]

9. Bertram, K.M.; Botting, R.A.; Baharlou, H.; Rhodes, J.W.; Rana, H.; Graham, J.D.; Patrick, E.; Fletcher, J.; Plasto, T.M.; Truong, N.R.; et al. Identification of HIV transmitting CD11c ${ }^{+}$human epidermal dendritic cells. Nat. Commun. 2019, 10, 2759. [CrossRef]

10. Smed-Sorensen, A.; Loré, K.; Vasudevan, J.; Louder, M.K.; Andersson, J.; Mascola, J.R.; Spetz, A.L.; Koup, R.A. Differential susceptibility to human immunodeficiency virus type 1 infection of myeloid and plasmacytoid dendritic cells. J. Virol. 2005, 79, 8861-8869. [CrossRef]

11. Kirchhoff, F. Immune evasion and counteraction of restriction factors by HIV-1 and other primate lentiviruses. Cell Host Microbe 2010, 8, 55-67. [CrossRef]

12. Hrecka, K.; Hao, C.; Gierszewska, M.; Swanson, S.K.; Kesik-Brodacka, M.; Srivastava, S.; Florens, L.; Washburn, M.P.; Skowronski, J. Vpx relieves inhibition of HIV-1 infection of macrophages mediated by the SAMHD1 protein. Nature 2011, 474, 658-661. [CrossRef] [PubMed]

13. Laguette, N.; Sobhian, B.; Casartelli, N.; Ringeard, M.; Chable-Bessia, C.; Segeral, E.; Yatim, A.; Emiliani, S.; Schwartz, O.; Benkirane, M. SAMHD1 is the dendritic-and myeloid-cell-specific HIV-1 restriction factor counteracted by Vpx. Nature 2011, 474, 654-657. [CrossRef] [PubMed]

14. Descours, B.; Cribier, A.; Chable-Bessia, C.; Ayinde, D.; Rice, G.; Crow, Y.; Yatim, A.; Schwartz, O.; Laguette, N.; Benkirane, M. SAMHD1 restricts HIV-1 reverse transcription in quiescent CD4(+) T-cells. Retrovirology 2012, 9, 87. [CrossRef] [PubMed]

15. Lahouassa, H.; Daddacha, W.; Hofmann, H.; Ayinde, D.; Logue, E.C.; Dragin, L.; Bloch, N.; Maudet, C.; Bertrand, M.; Gramberg, T.; et al. SAMHD1 restricts the replication of human immunodeficiency virus type 1 by depleting the intracellular pool of deoxynucleoside triphosphates. Nat. Immunol. 2012, 13, 223-228. [CrossRef]

16. Goldstone, D.; Ennis-Adeniran, V.; Hedden, J.J.; Groom, H.C.T.; Rice, G.I.; Christodoulou, E.; Walker, P.A.; Kelly, G.; Haire, L.F.; Yap, M.W. HIV-1 restriction factor SAMHD1 is a deoxynucleoside triphosphate triphosphohydrolase. Nature 2011, 480, 379-382. [CrossRef]

17. Posch, W.; Steger, M.; Knackmuss, U.; Blatzer, M.; Baldauf, H.M.; Doppler, W.; White, T.E.; Hörtnagl, P.; Diaz-Griffero, F.; Lass-Flörl, C.; et al. Complement-opsonized HIV-1 overcomes restriction in dendritic cells. PLoS Pathog. 2015, 11, e1005005. [CrossRef]

18. Bermejo-Jambrina, M.; Blatzer, M.; Jauregui-Onieva, P.; Yordanov, T.E.; Hörtnagl, P.; Valovka, T.; Huber, L.A.; Wilflingseder, D.; Posch, W. CR4 Signaling Contributes to a DC-Driven Enhanced Immune Response Against Complement-Opsonized HIV-1. Front. Immunol. 2020, 11, 2010. [CrossRef]

19. Posch, W.; Bermejo-Jambina, M.; Steger, M.; Witting, C.; Gabriel, D.; Hörtnagl, P.; Hubert, H.; Lass-Flörl, C.; Huber, L.A.; Geijtenbeek, T.B.H.; et al. Complement Potentiates Immune Sensing of HIV-1 and Early Type I Interferon Responses. $m B$ io 2021, 12, 5. [CrossRef]

20. Wilflingseder, D.; Bánki, Z.; Garcia, E.; Prünster, M.; Pfister, G.; Müllauer, B.; Nikolic, D.S.; Gassner, C.; Ammann, C.G.; Dierich, M.P.; et al. IgG Opsonization of HIV Impedes Provirus Formation in and Infection of Dendritic Cells and Subsequent Long-Term Transfer to T Cells. J. Immunol. 2007, 178, 7840-7848. [CrossRef]

21. Prünster, M.; Wilflingseder, D.; Bánki, Z.; Ammann, C.G.; Müllauer, B.; Meyer, M.; Speth, C.; Dierich, M.P.; Stoiber, H. C-type lectin-independent interaction of complement opsonized HIV with monocyte-derived dendritic cells. Eur. J. Immunol. 2005, 35, 2691-2698. [CrossRef]

22. Bajtay, Z.; Speth, C.; Erdei, A.; Dierich, M.P. Cutting Edge: Productive HIV-1 Infection of Dendritic Cells via Complement Receptor Type 3 (CR3, CD11b/CD18). J. Immunol. 2004, 173, 4775-4778. [CrossRef] [PubMed]

23. Bouhlal, H.; Chomont, N.; Réquena, M.; Nasreddine, N.; Saidi, H.; Legoff, J.; Kazatchkine, M.D.; Bélec, L.; Hochini, H. Opsonization of HIV with Complement Enhances Infection of Dendritic Cells and Viral Transfer to CD4 T Cells in a CR3 and DC-SIGN-Dependent Manner. J. Immunol. 2007, 178, 1086-1095. [CrossRef] [PubMed]

24. Harman, A.N.; Nasr, N.; Feetham, A.; Galoyan, A.; Alshehri, A.A.; Rambukwelle, D.; Botting, R.A.; Hiener, B.M.; Diefenbach, E.; Diefenbach, R.J.; et al. HIV Blocks Interferon Induction in Human Dendritic Cells and Macrophages by Dysregulation of TBK1. J. Virol. 2015, 89, 6575-6584. [CrossRef] [PubMed]

25. Bhattacharya, P.; Ellegård, R.; Khalid, M.; Svanberg, C.; Govender, M.; Keita, Å.V.; Söderholm, J.D.; Myrelid, P.; Shankar, E.M.; Nyström, S.; et al. Complement opsonization of HIV affects primary infection of human colorectal mucosa and subsequent activation of T cells. eLife 2020, 9, e57869. [CrossRef]

26. Stoiber, H.; Bánki, Z.; Wilflingseder, D.; Dierich, M.P. Complement HIV interactions during all steps of viral pathogenesis. Vaccine 2008, 26, 3046-3054. [CrossRef]

27. Bouhlal, H.; Chomont, N.; Haeffner-Cavaillon, N.; Kazatchkine, M.; Belec, L.; Hocini, H. Opsonization of HIV-1 by semen complement enhances infection of human epithelial cells. J. Immunol. 2002, 169, 3301-3306. [CrossRef]

28. Stoiber, H.; Pinter, C.; Siccardi, A.G.; Clivio, A.; Dierich, M.P. Efficient destruction of human immunodeficiency virus in human serum by inhibiting the protective action of complement factor $\mathrm{H}$ and decay accelerating factor (DAF, CD55). J. Exp. Med. 1996, 183, 307-310. [CrossRef] 
29. Frank, I.; Stoiber, H.; Godar, S.; Stockinger, H.; Steind, F.; Katinger, H.W.; Dierich, M.P. Acquisition of host cell-surface-derived molecules by HIV-1. AIDS 1996, 10, 1611-1620. [CrossRef]

30. Stoiber, H.; Söderholm, A.; Wilflingseder, D.; Gusenbauer, S.; Hildgartner, A.; Dierich, M.P. Complement and antibodies: A dangerous liaison in HIV infection? Vaccine 2008, 26 (Suppl. 8), 79-85. [CrossRef]

31. Ebenbichler, C.F.; Thielens, N.M.; Vornhagen, R.; Marschang, P.; Arlaud, G.J.; Dierich, M.P. Human immunodeficiency virus type 1 activates the classical pathway of complement by direct $C 1$ binding through specific sites in the transmembrane glycoprotein gp41. J. Exp. Med. 1991, 174, 1417-1424. [CrossRef]

32. Stoiber, H.; Thielens, N.M.; Ebenbichler, C.; Arlaud, G.J.; Dierich, M.P. The envelope glycoprotein of HIV-1 gp120 and human complement protein $\mathrm{C} 1 \mathrm{q}$ bind to the same peptides derived from three different regions of gp41, the transmembrane glycoprotein of HIV-1, and share antigenic homology. Eur. J. Immunol. 1994, 24, 294-300. [CrossRef] [PubMed]

33. Prohászka, Z.; Hidvégi, T.; Ujhelyi, E.; Stoiber, H.; Dierich, M.P.; Süsal, C.; Füst, G. Interaction of complement and specific antibodies with the external glycoprotein 120 of HIV-1. Immunology 1995, 85, 184-189. [PubMed]

34. Saifuddin, M.; Hedayati, T.; Atkinson, J.P.; Holguin, M.H.; Parker, C.J.; Spear, G.T. Human immunodeficiency virus type 1 incorporates both glycosyl phosphatidylinositol-anchored CD55 and CD59 and integral membrane CD46 at levels that protect from complement-mediated destruction. J. Gen. Virol. 1997, 78, 1907-1911. [CrossRef] [PubMed]

35. Nielsen, S.D.; Sørensen, A.M.; Schønning, K.; Lund, O.; Nielsen, J.O.; Hansen, J.E. Complement-mediated enhancement of HIV-1 infection in peripheral blood mononuclear cells. Scand. J. Infect. Dis. 1997, 29, 447-452. [CrossRef] [PubMed]

36. Rustom, A.; Saffrich, R.; Markovic, I.; Walther, P.; Gerdes, H.H. Nanotubular highways for intercellular organelle transport. Science 2004, 303, 1007-1010. [CrossRef] [PubMed]

37. Ariazi, J.; Benowitz, A.; De Biasi, V.; Den Boer, M.L.; Cherqui, S.; Cui, H.; Douillet, N.; Eugenin, E.A.; Favre, D.; Goodman, S.; et al Tunneling nanotubes and gap junctions-their role in long-range intercellular communication during development, health, and disease conditions. Front. Mol. Neurosci. 2017, 10, 333. [CrossRef] [PubMed]

38. Rustom, A. The missing link: Does tunnelling nanotube-based supercellularity provide a new understanding of chronic and lifestyle diseases? Open Biol. 2016, 6, 160057. [CrossRef]

39. Zhu, C.; Shi, Y.; You, J. Immune Cell Connection by Tunneling Nanotubes: The Impact of Intercellular Cross-Talk on the Immune Response and Its Therapeutic Applications. Mol. Pharm. 2021, 18, 772-786. [CrossRef]

40. Gerdes, H.H.; Bukoreshtliev, N.V.; Barroso, J.F. Tunneling nanotubes: A new route for the exchange of components between animal cells. FEBS Lett. 2007, 581, 2194-2201. [CrossRef]

41. Rescigno, M.; Urbano, M.; Valzasina, B.; Francolini, M.; Rotta, G.; Bonasio, R.; Granucci, F.; Kraehenbuhl, J.P.; Ricciardi-Castagnoli, P. Dendritic cells express tight junction proteins and penetrate gut epithelial monolayers to sample bacteria. Nat. Immunol. 2001, 2,361-367. [CrossRef]

42. Eugenin, E.A.; Gaskill, P.J.; Berman, J.W. Tunneling nanotubes (TNT) are induced by HIV-infection of macrophages: A potential mechanism for intercellular HIV trafficking. Cell. Immunol. 2009, 254, 142-148. [CrossRef] [PubMed]

43. Hashimoto, M.; Bhuyan, F.; Hiyoshi, M.; Noyori, O.; Nasser, H.; Miyazaki, M.; Saito, T.; Kondoh, Y.; Oada, H.; Kimura, S.; et al. Potential Role of the Formation of Tunneling Nanotubes in HIV-1 Spread in Macrophages. J. Immunol. 2016, 196, 1832-1841. [CrossRef] [PubMed]

44. Lotfi, S.; Nasser, H.; Noyori, O.; Hiyoshi, M.; Takeuchi, H.; Koyanagi, Y.; Suzu, S. M-Sec facilitates intercellular transmission of HIV-1 through multiple mechanisms. Retrovirology 2020, 17, 20. [CrossRef]

45. Lachambre, S.; Chopard, C.; Beaumelle, B. Preliminary characterisation of nanotubes connecting T-cells and their use by HIV-1. Biol. Cell 2014, 106, 394-404. [CrossRef] [PubMed]

46. Souriant, S.; Balboa, L.; Dupont, M.; Pingris, K.; Kviatcovsky, D.; Cougoule, C.; Lastrucci, C.; Bah, A.; Gasser, R.; Poincloux, R.; et al. Tuberculosis Exacerbates HIV-1 Infection through IL-10/STAT3-Dependent Tunneling Nanotube Formation in Macrophages. Cell Rep. 2019, 26, 3586-3599. [CrossRef]

47. Dupont, M.; Souriant, S.; Balboa, L.; V Manh, T.P.; Pingris, K.; Rousset, S.; Cougoule, C.; Rombouts, Y.; Poincloux, R.; Ben Neji, M.; et al. Tuberculosis-associated IFN-I induces Siglec-1 on tunneling nanotubes and favors HIV-1 spread in macrophages. eLife 2020, 9, e52535. [CrossRef]

48. Kadiu, I.; Gendelman, H.E. Human immunodeficiency virus type 1 endocytic trafficking through macrophage bridging conduits facilitates spread of infection. J. Neuroimmune Pharmacol. 2011, 6, 658-675. [CrossRef]

49. Sowinski, S.; Jolly, C.; Berninghausen, O.; Purbhoo, M.A.; Chauveau, A.; Köhler, K.; Oddos, S.; Eissmann, P.; Brodsky, F.M.; Hopkins, C.; et al. Membrane nanotubes physically connect T cells over long distances presenting a novel route for HIV-1 transmission. Nat. Cell. Biol. 2008, 10, 211-219. [CrossRef]

50. Aggarwal, A.; Hitchen, T.L.; Ootes, L.; McAllery, S.; Wong, A.; Nguyen, K.; McCluskey, A.; Robinson, P.J.; Turville, S.G. HIV infection is influenced by dynamin at 3 independent points in the viral life cycle. Traffic 2017, 18, 392-410. [CrossRef]

51. Aggarwal, A.; Iemma, T.L.; Shih, I.; Newsome, T.P.; McAllery, S.; Cunningham, A.L.; Turville, S.G. Mobilization of HIV spread by diaphanous 2 dependent filopodia in infected dendritic cells. PLoS Pathog. 2012, 8, e1002762. [CrossRef]

52. Zaccard, C.R.; Watkins, S.C.; Kalinski, P.; Fecek, R.J.; Yates, A.L.; Salter, R.D.; Ayyavoo, V.; Rinalso, C.R.; Mailliard, R.B. CD40L Induces Functional Tunneling Nanotube Networks Exclusively in Dendritic Cells Programmed by Mediators of Type 1 Immunity. J. Immunol. 2015, 194, 1047-1056. [CrossRef] [PubMed] 
53. Omsland, M.; Bruserud, Ø.; Gjertsen, B.T.; Andresen, V. Tunneling nanotube (TNT) formation is downregulated by cytarabine and NF- $\mathrm{kB}$ inhibition in acute myeloid leukemia (AML). Oncotarget 2017, 8, 7946-7963. [CrossRef] [PubMed]

54. Posch, W.; Lass-Flörl, C.; Wilflingseder, D. Generation of Human Monocyte-derived Dendritic Cells from Whole Blood. J. Vis. Exp. 2016, 118, 54968. [CrossRef] [PubMed]

55. Posch, W.; Cardinaud, S.; Hamimi, C.; Fletcher, A.; Muhlbacher, A.; Loacker, K.; Eichberger, P.; Dierich, M.P.; PAncino, G.; Lass-Flörl, C.; et al. Antibodies attenuate the capacity of dendritic cells to stimulate HIV-specific cytotoxic T lymphocytes. J. Allergy Clin. Immunol. 2012, 130, 1368-1374. [CrossRef]

56. FACSDiva; Version 8; BD Biosciences: Franklin Lakes, NJ, USA, 2020. Available online: https://www.bdbiosciences.com/en-eu/ products/software/instrument-software/bd-facsdiva-software\#Overview (accessed on 15 December 2021).

57. Purtscher, M.; Trkola, A.; Gruber, G.; Buchacher, A.; Predl, R.; Steindl, F.; Tauer, C.; Berger, R.; Barrett, N.; Jungbauer, A.; et al. broadly neutralizing human monoclonal antibody against gp41 of human immunodeficiency virus type 1 . AIDS Res. Hum. Retroviruses 1994, 10, 1651-1658. [CrossRef]

58. Harmony Software, Version 4.8, Perkin Elmer. Available online: https://www.perkinelmer.com/uk/product/harmony-4-8-officehh17000001 (accessed on 20 December 2021).

59. Hanna, S.J.; McCoy-Simandle, K.; Miskolci, V.; Guo, P.; Cammer, M.; Hodgson, L.; Cox, D. The Role of Rho-GTPases and actin polymerization during Macrophage Tunneling Nanotube Biogenesis. Sci. Rep. 2017, 7, 8547. [CrossRef]

60. Graphpad Prism; Version 9; GraphPad Software Inc.: San Diego, CA, USA. Available online: https://www.graphpad.com (accessed on 21 January 2021).

61. Gerdes, H.H.; Rustom, A. Cell-Cell Channels. In Tunneling Nanotubes; Springer: New York, NY, USA, 2006. [CrossRef]

62. Omsland, M.; Pise-Masison, C.; Fujikawa, D.; Galli, V.; Fenizia, C.; Washington Parks, R.; Gjertsen, B.T.; Franchini, G.; Andresen, V. Inhibition of Tunneling Nanotube (TNT) Formation and Human T-cell Leukemia Virus Type 1 (HTLV-1) Transmission by Cytarabine. Sci. Rep. 2018, 8, 11118. [CrossRef]

63. Shih, V.F.; Davis-Turak, J.; Macal, M.; Huang, J.Q.; Ponomarenko, J.; Kearns, J.D.; Yu, T.; Fagerlund, R.; Asagiri, M.; Zuniga, E.I.; et al. Control of RelB during dendritic cell activation integrates canonical and noncanonical NF- $\mathrm{kB}$ pathways. Nat. Immunol. 2012, 13, 1162-1170. [CrossRef]

64. Oh, H.; Ghosh, S. NF-кB: Roles and regulation in different CD4(+) T-cell subsets. Immunol. Rev. 2013, 252, 41-51. [CrossRef]

65. Uhl, J.; Gujarathi, S.; Waheed, A.A.; Gordon, A.; Freed, E.O.; Gousset, K. Myosin-X is essential to the intercellular spread of HIV-1 Nef through tunneling nanotubes. J. Cell. Commun. Signal. 2019, 13, 209-224. [CrossRef]

66. Mukerji, J.; Olivieri, K.C.; Misra, V.; Agopian, K.A.; Gabuzda, D. Proteomic Analysis of HIV-1 Nef Cellular Binding Partners Reveals a Role for Exocyst Complex Proteins in Mediating Enhancement of Intercellular Nanotube Formation. Retrovirology 2012, 9, 33. [CrossRef] [PubMed]

67. Quaranta, M.G.; Mattioli, B.; Spadaro, F.; Straface, E.; Giordani, L.; Ramoni, C.; Malorni, W.; Viora, M. HIV-1 Nef triggers Vav-mediated signaling pathway leading to functional and morphological differentiation of dendritic cells. FASEB J. 2003, 17, 2025-2036. [CrossRef] [PubMed]

68. Dhainaut, M.; Moser, M. Regulation of immune reactivity by intercellular transfer. Front. Immunol. 2014, 5, 112. [CrossRef] [PubMed]

69. Campana, S.; De Pasquale, C.; Carrega, P.; Ferlazzo, G.; Bonaccorsi, I. Cross-dressing: An alternative mechanism for antigen presentation. Immunol. Lett. 2015, 168, 349-354. [CrossRef]

70. Zaccard, C.R.; Rinaldo, C.R.; Mailliard, R.B. Linked in: Immunologic membrane nanotube networks. J. Leukoc. Biol. 2016, 100, 81-94. [CrossRef]

71. Kumar, A.; Kim, J.H.; Ranjan, P.; Metcalfe, M.G.; Cao, W.; Mishina, M.; Gangappa, S.; Guo, Z.; Boyden, S.E.; Zaki, S.; et al. Influenza Virus Exploits Tunneling Nanotubes for Cell-to-Cell Spread. Sci. Rep. 2017, 7, 40360. [CrossRef]

72. Schneider, C.; Oellerich, T.; Baldauf, H.M.; Schwarz, S.M.; Thomas, D.; Flick, R.; Bohnenberger, H.; Kaderali, L.; Stegmann, L.; Cremer, A.; et al. SAMHD1 is a biomarker for cytarabine response and a therapeutic target in acute myeloid leukemia. Nat. Med. 2017, 23, 250-255. [CrossRef]

73. Gröschel, B.; Kaufmann, A.; Cinatl, J.; Doerr, H.W. Cytarabine treatment of human T-lymphoid cells induces decreased HIV-1 receptor expression and reduced HIV-1 susceptibility. Nucleosides Nucleotides Nucleic Acids 2001, 20, 1433-1437. [CrossRef]

74. Soederholm, A.; Bánki, Z.; Wilflingseder, D.; Gassner, C.; Zwirner, J.; López-Trascasa, M.; Falkensammer, B.; Dierich, M.; Stoiber, H. HIV-1 induced generation of C5a attracts immature dendritic cells and promotes infection of autologous T cells. Eur. J. Immunol. 2007, 37, 2156-2163. [CrossRef]

75. Wilflingseder, D.; Schroll, A.; Hackl, H.; Gallasch, R.; Frampton, D.; Lass-Flörl, C.; Pancino, G.; Saez-Cirion, A.; Lambotte, O.; Weiss, L.; et al. Immediate T-Helper 17 Polarization Upon Triggering CD11b/c on HIV-Exposed Dendritic Cells. J. Infect. Dis. 2015, 212, 44-56. [CrossRef]

76. Posch, W.; Vosper, J.; Noureen, A.; Zaderer, V.; Witting, C.; Bertacchi, G.; Gstir, R.; Filipek, P.A.; Bonn, G.K.; Huber, L.A.; et al. $\mathrm{C} 5 \mathrm{aR}$ inhibition of nonimmune cells suppresses inflammation and maintains epithelial integrity in SARS-CoV-2-infected primary human airway epithelia. J. Allergy Clin. Immunol. 2021, 147, 2083-2097. [CrossRef] [PubMed]

77. Vaibhav, T.; Raghuram, K.; Greer, R.; Ananya, S.; Deepak, S. Role of Tunneling Nanotubes in Viral Infection, Neurodegenerative Disease, and Cancer. Front. Immunol. 2021, 12, 2256. [CrossRef] 